\title{
ANALISIS PERAN TEORI KOMUNIKASI UNTUK MENCAPAI \\ TUJUAN KHOTBAH YANG KOMUNIKATIF DI \\ GEREJA KIBAID KLASIS MAKASSAR
}

\author{
Yonatan Salong \\ ysalong@yahoo.com \\ Daniel Ronda
}

\begin{abstract}
ABSTRAK
Yonatan Salong, Analisis peran teori komunikasi dalam mencapai tujuan khotbah yang komunikatif di gereja Kerapatan Injil Bangsa Indonesia (KIBAID) klasis makassar.

Adapun tujuan penulisan karya ilmiah ini adalah: menjelaskan hubungan antara khotbah yang komunikatif dengan penerapan khotbah hamba Tuhan di Gereja KIBAID Makassar.

Penulisan karya ilmiah ini diselesaikan dengan menggunakan metode penelitian kuantitatif. Penelitian ini didukung oleh penelitian lapangan dan penelitian pustaka. Penelitian lapangan dilakukan dengan teknik observasi langsung, interview dan questioner.

Hasil penelitian menunjukkan: Pertama, untuk mencapai tujuan khotbah yang komunikatif dalam jemaat, harus memperhatikan unsur-unsur komunikasi. Unsurunsur ini harus dapat bersinergi, seperti pada peran pesan, peran komunikator, peran komunikan, peran cara menyampaikan, peran hasil, dan peran feedback. Kedua, Pesan dalam khotbah merupakan pesan yang bersumber dari Allah yang didapatkan/dibaca lewat Alkitab. Pesan disampaikan untuk manusia sesuai dengan kebutuhannya, bukan berdasarkan kemauan atau keinginan pengkhotbahnya. Ketiga, komunikator atau seorang pengkhotbah adalah orang yang mendapat panggilan khusus menjadi seorang pengkhotbah. Seorang yang mampu menyampaikan pesan Firman Tuhan secara arif dan profesional, agar jemaat atau komunikan dapat mengalami hidup yang penuh dengan kataatan kepada Tuhan.
\end{abstract}

Kata kunci: Khotbah, Komunikasi, Komunikatif, Gereja KIBAID 


\section{PENDAHULUAN}

\section{Latar Belakang Masalah}

Khotbah adalah pelayanan rohani, Hasan Sutanto membenarkan hal itu bahwa; "Berkhotbah adalah pelayanan yang bersifat rohani." Selain adalah pelayanan rohani khotbah juga begitu penting dalam kehidupan sebuah gereja. diibaratkan sebuah pohon, khotbah adalah pokok utama dari cabang, ranting, dan daun-daunnya, demikian khotbah pada ibadah di gereja. Membenarkan hal itu Andreas B. Subagyo, bahwa: "Pelayanan Firman adalah pelayanan yang sangat penting. Jika tidak, pasti para rasul tidak ingin memusatkan pikiran dalam doa dan pelayanan firman. Juga, pastilah Rasul Paulus tidak memerintahkan agar "Beritakanlah firman, siap sedialah baik atau tidak baik waktunya"' (II Timotius $4: 2)^{2}$ bahwa:

Lebih lanjut akan pentingnya khotbah, oleh Andreas B. Subagyo,

Khotbah selalu merupakan keperluan, karena khotbah begitu terkait pada kehidupan gereja. Pemberitaan kabar baiklah yang menjadikan gereja ada; dan hanya pemberitaan itu pulalah yang dapat menjaga kehidupan di gereja. Catatan sejarah Kristen telah menunjukkan bahwa kekuatan gereja secara langsung berhubungan dengan kekuatan mimbar. Apabila berita dari mimbar tidak mantap dan goyah, maka gereja lemah; apabila mimbar menyajikan berita yang pasti, dan tegas, maka gereja kuat. Khotbah yang efektif sangat perlu, .... Khotbah sangat penting bagi kekristenan. ${ }^{3}$

Hal senada oleh Eka Darmaputra dalam bukunya Menyembah dalam Roh dan Kebenaran demikian:

Khotbah itu penting. Bahkan, bagi sebagian orang, khotbah itulah satu-satunya yang penting. Karena itu, ada yang beranggapan datang terlambat pun tidak apa-apa, asal masih sempat mendengar khotbah $" 4$

Homiletika atau ilmu berkhotbah. Muncul pada abad XVII, yang dalam bahasa Inggrisnya disebut homiletics. Pada abad ke 17 itulah, kata

\footnotetext{
${ }^{1}$ Hasan Sutanto, Homiletik, Prinsip dan Metode Berkhotbah. (Jakarta: BPK Gunung Mulia. 2004), 173.

2 Andreas B. Subagyo, Sabda dalam Kata, Persiapannya. (Bandung: Yayasan Kalam Hidup, 2000), 7.

${ }^{3}$ Ibid

${ }^{4}$ Eka Darmaputra, Menyembah dalam Roh dan Kebenaran. (Jakarta: BPK Gunung Mulia. 2002), 1.
} 
ini dipakai untuk menunjukkan ilmu berkhotbah, ${ }^{5}$ atau ilmu menyampaikan khotbah. Menurut Hasan Sutanto:

Di kalangan orang Kristen, arti sempit kata ini menunjuk kepada suatu mata pelajaran teologi praktis, di seminari yang mengajar mahasiswa/i membuat dan menyampaikan khotbah. Arti luas kata ini menunjuk studi berkhotbah. Jadi homiletik berkaitan dengan penyelidikan, pembahasan, pengembangan ilmu dan praktik berkhotbah. Homiletika berhubungan dengan teologi (atau ilmu) dan seni. Dikatakan berhubungan dengan ilmu, karena dalam sebuah khotbah terdapat unsur teologi, atau yang lebih tepat, penafsiran Alkitab. Dikatakan berhubungan dengan seni, karena unsur penting dalam khotbah, yaitu penafsiran Alkitab juga berkaitan sengan seni. Selain itu penyusunan dan penyampaian khotbah, juga berhubungan dengan retorika. Retorika adalah seni berpidato, seni ini perlu dikuasai setiap pengkhotbah. Walaupun homiletik berhubungan dengan retorika, tetapi homiletik bukanlah cabang retorik, melainkan cabang teologi. Dengan mempelajari homiletik, diharapkan seorang pengkhotbah dapat menulis naskah khotbah yang rapi berdasarkan Alkitab, lalu menyampaikannya dengan meyakinkan, berwibawa, jelas, dan menarik. ${ }^{6}$

Memahami dan memperkuat ilmu homiletika, memampukan seorang pengkhotbah dapat menyelidiki, menafsirkan Alkitab, dan menyampaikan khotbahnya dengan meyakinkan, berwibawa, jelas dan menarik.

Selanjutnya, untuk mencapai tujuan khotbah yang komunikastif, tidak cukup seseorang hanya dapat memahami dan memperkuat homiletik, tetapi harus ditambahkan dengan pemahaman ilmu komunikasi yang baik. Hasan Sutanto menekankan bahwa untuk menyampaikan khotbah yang meyakinkan, berwibawa, jelas dan menarik diperlukan pengetahuan yang lain, yaitu ilmu komunikasi. Jelasnya:

Komunikasi lisan memainkan peran penting dalam pelayanan berkhotbah. Pengkhotbah yang mahir dalam berkomunikasi sudah tentu lebih mungkin mendapat hasil yang diharapkan. Komunikasi lisan yang baik mencirikan jelas, manarik, indah (atau menyenangkan), informatif, meyakinkan, merangsang pikiran, mengharukan, memenuhi kebutuhan (misalnya memberi solusi akan

\footnotetext{
${ }^{5}$ Hasan Sutanto, Homiletik, Prinsip dan Metode Berkhotbah. (Jakarta: BPK Gunung Mulia. 2004). 3.

${ }^{6}$ Ibid.
} 
suatu masalah), membantu komunikan bertekat mengambil tindakan, dan lain-lain.

Antara homiletik dan ilmu komunikasi terdapat keterkaitan yang saling melengkapi untuk mecapai tujuan khotbah yang komunikatif, disederhanakan seperti berikut:

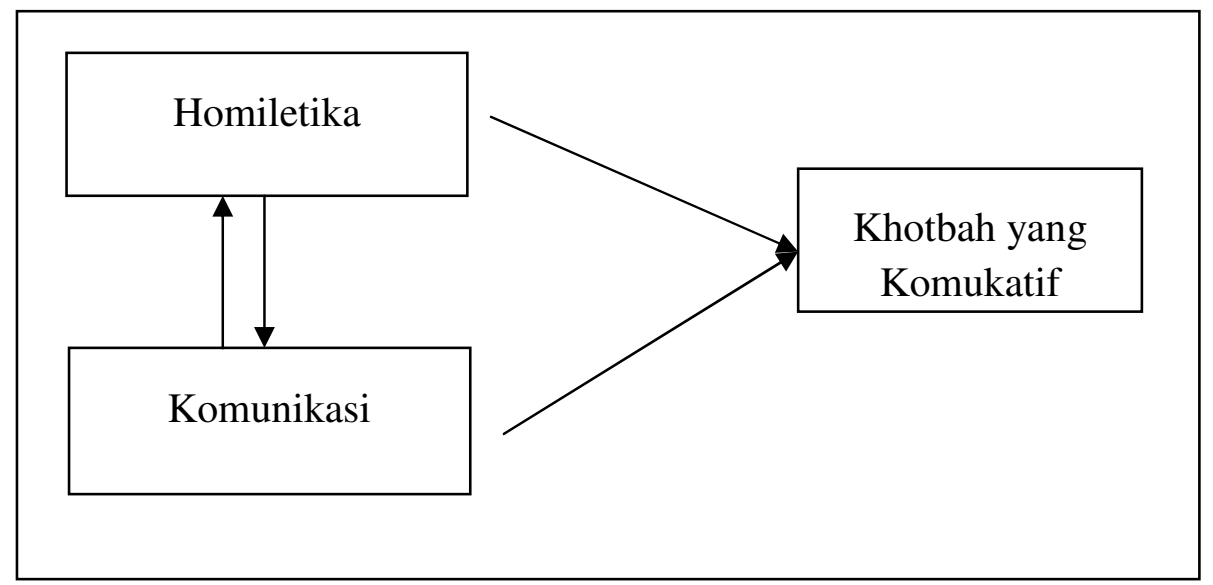

Dalam ilmu komunikasi ada pembawa berita dan penerima pesan. Komunikasi itu sendiri sangat dipengaruhi oleh konteks komunikator, dan konteks penerimanya (komunikan). Harmonisasi dan rusaknya komunikasi, terlihat dari efek atau arus baliknya (feedback). Dalam berkomunikasi, melibatkan komponen-komponen sebagai berikut: konteks, sumber, penerima, pesan, saluran, gangguan, proses penyampaian atau proses encoding, penerima atau proses decoding, arus balik dan efek.

Komunikatif dapat berarti: dalam keadaan saling dapat berhubungan (mudah dihubungi); dan mudah dipahami (dimengerti): bahasanya sangat komunikatif sehingga pesan yg disampaikannya dapat diterima dengan baik.

Mengkomunikasikan pesan Firman Tuhan, tentunya akan mempertimbangkan komunikan. Dalam proses berkomunikasi penerima akan menunjukkan respon yang ragam dalam ilmu komunikasi, proses ini disebut encoding. Proses ini sangat dipengaruhi oleh latar belakang hidup pribadi dan latar belakang keluarga dari komunikator, termasuk latar belakang pendidikan, suku, dan budayanya (feedback). Disinilah khotbah yang kominikatif terjadi ketika pengkhotbah dapat menterjemahkan respon pendengar, kemudian pengkhotbah dapat

\footnotetext{
${ }^{7}$ http://www.artikata.com/arti-335897-komunikatif.html
} 
membahasakan firman Tuhan dengan lebih lugas, dapat dimengerti dan dipahami oleh semua kalangan.

Mengenai khotbah yang dikatagorikan khotbah komunikatif atau tidak, berdasarkan keterangan salah seorang pengerja Gereja KIBAID di Jemaat X, berinisial TA menyebutkan, "Saat ini khotbah yang dikatakan khotbah komunikatif belum ada di Gereja KIBAID Klasis Makassar, dan belum dapat dipastikan jika suatu saat akan ada perubahan.." Pendapat yang serupa dan dipeoleh melalui wawancara jauh hari sebelumnya kepada saudara Amran, anggota Persekutuan Kaum Muda (PKM) Gereja KIBAID Jemaat X Klasis Makassar, mengatakan:

Sekarang ini, umumnya banyak hamba Tuhan atau pengkhotbah tidak kominikatif ketika berkhotbah. Terlihat dari khotbahkhotbahnya yang monoton, tidak sesuai dengan kebutuhan jemaat. Selain itu, banyak khotbah yang melenceng dari kebenaran firman yang baru saja dibacakan. Pengkhotbah terpancing untuk lebih banyak berbicara ke-"aku"-annya, tentang kelebihan dan kehebatannya dari pada kemuliaan Tuhan, dalam menjelaskan firman Tuhan. Akibatnya pesan yang disampaikan itu ngambang atau tidak dimengerti maksudnya. Meski demikian, ada juga di antara hamba Tuhan, ketika berkhotbah fokus dalam pemberitaan Firman Tuhan, sehingga pesan yang disampaikan dapat dimengerti dengan jelas. ${ }^{9}$

Dorongan rasa ingin tahu lebih dalam mengenai hal ini, maka penulis mencoba untuk mengadakan penilitian dan dituliskan dalam bentuk karya ilmiah, dengan judul: "ANALISIS PERAN TEORI KOMUNIKASI DALAM MENCAPAI TUJUAN KHOTBAH YANG KOMUNIKATIF DI GEREJA KIBAID KLASIS MAKASSAR".

\section{Rumusan Masalah}

Sehubungan dengan latar belakang di atas, maka dalam penulisan karya ilmiah menjawab pokok masalah berikut ini: "Sejauhmana hubungan antara khotah yang komunikatif dengan penerapan khotbah hamba-hanba Tuhan di Gereja KIBAID Makassar?."

\section{Tujuan Penulisan}

Karya ilmiah ini bertujuan untuk: "Menjelaskan hubungan antara khotbah yang komunikatif dengan penerapan khotbah hamba Tuhan di Gereja KIBAID Makassar."

\footnotetext{
${ }^{8}$ TA (inisial) Wawancara dengan penulis, 21 Maret 2009

${ }^{9}$ Amran, Wawancara dengan penulis, 03 Pebruari 2009
} 


\section{Manfaat Penulisan}

Manfaat praktis dari penelitian ini adalah untuk memberikan masukan kepada: Pertama, hamba Tuhan sebagai komunikator atau pembawa pesan Firman Tuhan, untuk menemukan pemikiran tentang pentingnya peran teori komunikasi dalam mencapai tujuan khotbah yang komunikatif di lingkungan Gereja KIBAID Klasis Makassar. Kedua, Jemaat atau pendengar sebagai komunikan dan penilai, memberikan informasi dan masukan yang positif kepada hamba Tuhan (komunikator), mengenai perlunya peran teori komunikasi dalam mencapai tujuan khtobah yang komunikatif.

\section{Metode Penelitian}

Penulisan karya ilmiah ini diselesaikan dengan menggunakan metode penelitian kuantitatif. Penelitian ini didukung oleh penelitian lapangan dan penelitian pustaka. Penelitian lapangan dilakukan dengan teknik observasi langsung, interview dan questioner.

\section{Jenis Penelitian}

\section{METODOLOGI PENELITIAN}

Jenis penelitian yang digunakan dalam penelitian dalam menyelesaikan penulisan karya ilmiah ini adalah penelitian kuantitatif. Basrowi \& Sukidin, menjelaskan "Penelitian kualitatif adalah jenis penelitian yang menghasilkan penemuan-penemuan yang tidak dapat dicapai dengan menggunakan statistik atau dengan cara kuantifikasi lainnya."

Penelitian kuantitatif dalam karya ilmiah ini berpedoman pada buku Pegantar Riset Kuantitaif dan Kualitatif karya Andreas B. Subagyo. Menurut Andreas B. Subagyo, "peneliti harus menentukan analisis statistik mana yang akan dipakai. Hal tersebut, pertama-tama, ditentukan oleh tingkat pengukuran yang akan dilakukan atau jenis data yang dikumpulkan."11

\section{Teknik Pengumpulan Data}

Untuk memperoleh data yang objektif, penulis menggunakan teknik pengumpulan data melalui beberapa cara, di antaranya: Mendengarkan khotbah-khotbah pendeta di Gereja KIBAID Klasis Makassar dan penelitian lapangan yang meliputi: Observasi, Interview, 2002), 1 .

${ }^{10}$ Basrowi \& Sukidin, Metode Penelitian Kualitatif. (Surabaya: Insan Cendekia,

${ }^{11}$ Andreas B. Subagyo, Pegantar Riset Kuantitatif dan Kualitatif. Bandung: (Yayasan Kalam Hidup, 2004), 246. 


\section{Teknik Analisis Data}

Data yang dikumpul melalui Questioner dianalisis dengan beberapa cara, di antaranya: Komparasi, Intepretasi, Deskripsi, Deduksi induksi.

\section{Rumus}

Rumus yang digunakan dalam analisa data, adalah sebagai berikut:

$$
\begin{aligned}
& \text { Skor }
\end{aligned}
$$

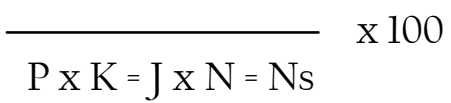

$$
\begin{aligned}
& \text { Ket: } \\
& \mathrm{P}=\text { Populasi } \\
& \mathrm{K}=\text { Kodifikasi } \\
& \mathrm{J}=\text { Jumlah } \\
& \mathrm{N}=\text { Nilai } \\
& \text { Ns = Nilai Skor }
\end{aligned}
$$

\section{PENYAJIAN DAN ANALISIS DATA}

\section{Penyajian Data}

Jenis penelitian yang digunakan oleh penulis adalah jenis penelitian kuantitatif. Perolehan data didapatkan melalui pertanyaan questioner kepada anggota jemaat dari sebelas gereja lokal, dan Gembala Sidang Gereja KIBAID Klasis Makassar.

Dalam angket penelitian, penulis menggunakan 6 item pokok, kemudian dijabarkan ke dalam 42 pertanyaan. Item-item tersebut meliputi, item pesan/khotbah, item konteks komunikator/sumber, item pengenalan komunikator pada komunikan, item cara penyampaian, item hasil, dan item feedback. Setiap item diturunkan 7 pertanyaan, dan setiap pertanyaan yang diajukan memerlukan jawaban A (Sangat Setuju), B (Setuju), C (Kurang Setuju) dan D (Tidak Setuju) dari responden. Setiap jawaban memiliki nilai skor, untuk jawaban A nilai skornya 4, jawaban B nilai skornya 3, jawaban C nilai skornya 2, dan jawaban D nilai skornya 1 . Dalam pembuatan dan penghitungan data pada tabel-tabel menggunakan program Statistical Package for the Social Science (SPSS).

Sebagaimana yang dimaksudkan dalam metodologi penelitian, bahwa untuk mendapatkan jumlah atau nilai prosentase, maka 
digunakan rumus Skor dikalikan 100, hasil tersebut dibagi $\mathrm{P} \times \mathrm{K}=\mathrm{J}$ x N = Ns, hasilnya adalah nilai prosentase. Setiap item memiliki nilai skor maksimal 28 point dan nilai skor minimal 7 point (jumlah ini dapat berubah). Sebagai contoh, apabila satu item hanya mendapatkan skor 20 point, jumlah ini dikalikan 100, kamudian dibagi dengan nilai skor maksimal, hasilnya prosentasenya $71,42 \%$.

\section{Item Pesan}

Questioner pada item pesan diturunkan 7 pertanyaan sebagai identifikasi pokok masalah, di antaranya; Pertama, pesan yang disampaikan dalam khotbah harus merupakan pesan yang bersumber dari Alkitab. Kedua, pesan khotbah diuraikan berdasarkan teks atau konteks kitab yang telah dibacakan. Ketiga, pesan khotbah itu hendaknya bersifat universal, relevan dan sesuai dengan kebutuhan komunikannya. Keempat, pesan khotbah juga hendaknya bersifat aktual, sesuai dengan situasi dan kondisi komunikannya. Kelima, menyampaikan pesan dalam khotbah tidak dengan nada kesombongan pribadi oleh komunikator kepada komunikan. Keenam, komunikator atau pengkhotbah perlu menghindari kesan pilih kasih di antara pendengarnya pada saat menyampaikan pesan khotbahnya. Ketujuh, pesan khotbah juga selayaknya mengalami peningkatan, kemajuan dan pembaruan sesuai dengan kemajuan dan perkembangan ilmu pengetahuan.

Tabel 1

Statistik Item Pesan Khotbah

\begin{tabular}{|rl|r|r|r|r|}
\hline & & Frequency & Percent & Valid Percent & $\begin{array}{c}\text { Cumulative } \\
\text { Percent }\end{array}$ \\
\hline Valid & 14 & 2 & 1,0 & 1,0 & 1,0 \\
& 17 & 3 & 1,5 & 1,5 & 2,5 \\
& 18 & 8 & 4,0 & 4,0 & 6,5 \\
19 & 14 & 7,0 & 7,0 & 13,5 \\
20 & 17 & 8,5 & 8,5 & 22,0 \\
21 & 26 & 13,0 & 13,0 & 35,0 \\
22 & 15 & 7,5 & 7,5 & 42,5 \\
23 & 21 & 10,5 & 10,5 & 53,0 \\
24 & 31 & 15,5 & 15,5 & 68,5 \\
25 & 17 & 8,5 & 8,5 & 77,0 \\
26 & 16 & 8,0 & 8,0 & 85,0 \\
27 & 4 & 2,0 & 2,0 & 87,0 \\
28 & 26 & 13,0 & 13,0 & 100,0 \\
Total & 200 & 100,0 & 100,0 & \\
\hline
\end{tabular}


Distribusi frequency yang ditampilkan menunjukkan jumlah responden terendah, yaitu 2 dengan nilai skor 14 sampai jumlah responden tertinggi, yaitu 26 dengan nilai skor 28. Pada statistic ini disertai dengan informasi tentang jumlah prosentasenya, responden dengan jumlah persentase dari yang terendah yaitu; 1,0\% sebanyak 2 orang, 1,5\% sebanyak 3 orang, 2,0\% sebanyak 4 orang, 4,0\% sebanyak 8 orang, $7,0 \%$ sebanyak 14 orang, $7,5 \%$ sebanyak 15 orang, $8,0 \%$ sebanyak 16 orang, 8,5\% sebanyak 34 orang, 10,5\% sebanyak 21 orang, $13,0 \%$ sebanyak 52 orang, sampai jumlah persentase tertinggi menempati hanya 15,5\% sebanyak 31 orang. Bentuk distribusi di atas dapat diketahui dari grafik Histogram dan kurev normalnya. Dari tampilan grafik di bawah ini dapat dilihat bahwa distribusi variabel item pesan berbentuk tidak normal atau tidak merata. Ini disebabkan karena faktor jumlah prosentase yang relatif bervariasi.

\section{Histogram}

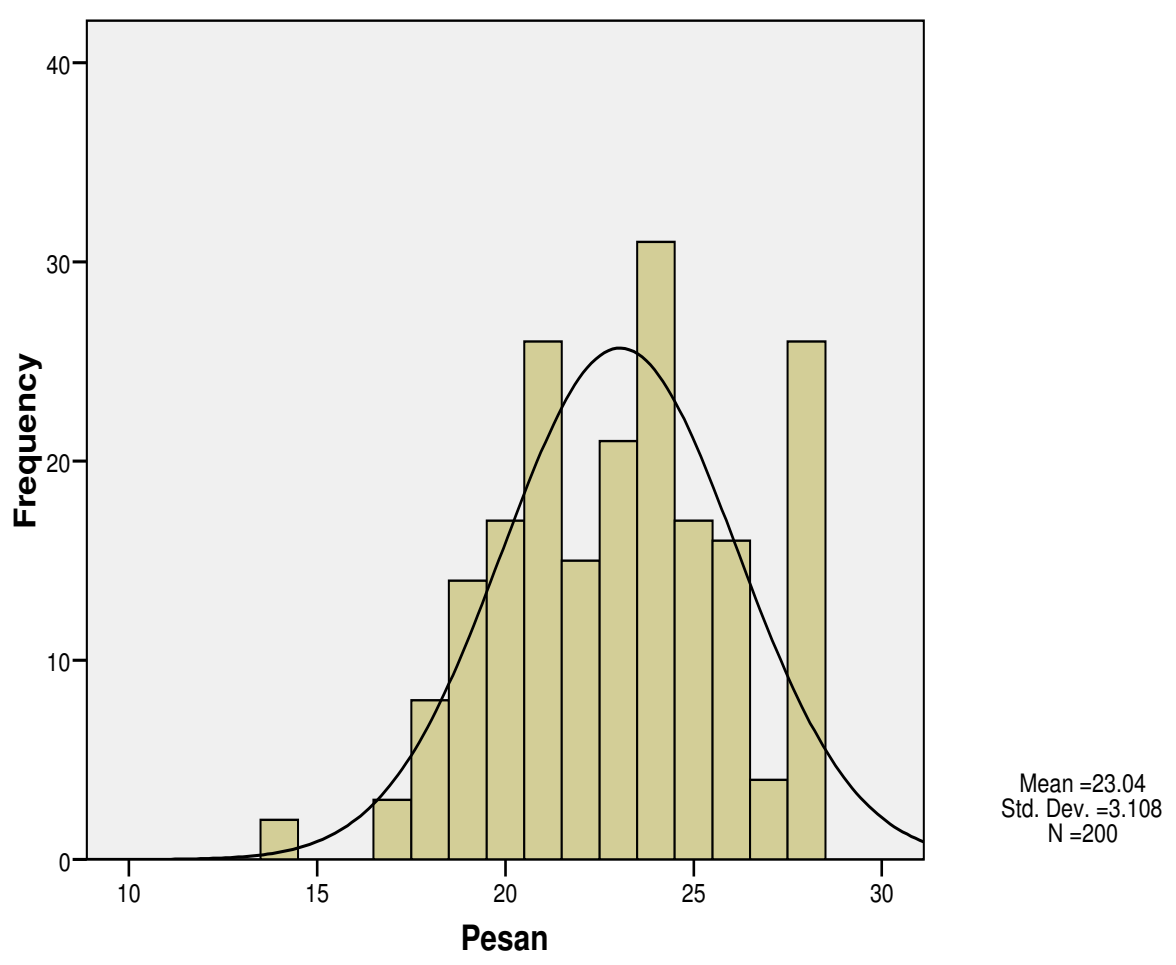

Item Konteks Komunikator/Sumber

Questioner pada item konteks komunikator/sumber diturunkan 7 pertanyaan sebagai identifikasi pokok masalah, di antaranya; Pertama, 
seorang komunikator atau pengkhotbah adalah seorang yang telah lahir baru yang dipangil Tuhan untuk melayani-Nya, Kedua, seorang komunikator atau pengkhotbah berkomitmen untuk fokus pada teks yang telah dibacakan. Ketiga, seorang komunikator atau pengkhotbah adalah seorang yang telah mengenal dengan baik komunikannya. Keempat, seorang komunikator atau pengkhotbah terus meningkatkan kemampuannya melalui belajar dan membaca. Kelima, komunikator atau pengkhotbah mempunyai kemampuan untuk berkomunikasi kepada lingkungan dan masyarakat, khususnya kepada komunikannya. Keenam, seorang komunikator atau pengkhotbah mampu melakukan tugasnya secara profesional, dan berpengalaman di bidangnya. Ketujuh, seorang komunikator atau pengkhotbah sedapat mungkin berasal dari suku atau budaya yang sama dengan pendengarnya.

Tabel 2

Statistik Item Konteks Komunikator/Sumber

\begin{tabular}{|c|c|c|c|c|c|}
\hline & & Frequency & Percent & $\begin{array}{c}\text { Valid } \\
\text { Percent }\end{array}$ & $\begin{array}{c}\text { Cumulative } \\
\text { Percent }\end{array}$ \\
\hline Valid & 13 & 3 & 1,5 & 1,5 & 1,5 \\
\hline & 15 & 6 & 3,0 & 3,0 & 4,5 \\
\hline & 16 & 7 & 3,5 & 3,5 & 8,0 \\
\hline & 17 & 22 & 11,0 & 11,0 & 19,0 \\
\hline & 18 & 16 & 8,0 & 8,0 & 27,0 \\
\hline & 19 & 30 & 15,0 & 15,0 & 42,0 \\
\hline & 20 & 29 & 14,5 & 14,5 & 56,5 \\
\hline & 21 & 28 & 14,0 & 14,0 & 70,5 \\
\hline & 22 & 24 & 12,0 & 12,0 & 82,5 \\
\hline & 23 & 19 & 9,5 & 9,5 & 92,0 \\
\hline & 24 & 3 & 1,5 & 1,5 & 93,5 \\
\hline & 25 & 4 & 2,0 & 2,0 & 95,5 \\
\hline & 26 & 7 & 3,5 & 3,5 & 99,0 \\
\hline & 28 & 2 & 1,0 & 1,0 & 100,0 \\
\hline & Total & 200 & 100,0 & 100,0 & \\
\hline
\end{tabular}

Distribusi frequency yang ditampilkan menunjukkan jumlah responden terendah, yaitu 3 dengan nilai skor 13 sampai jumlah responden tertinggi, yaitu 2 dengan nilai skor 28. Pada statistic ini disertai dengan informasi tentang jumlah prosentasenya, responden dengan jumlah prosentase dari yang terendah, yaitu 1,0\% sebanyak 2 orang, $1,5 \%$ sebanyak 6 orang, 2,0\% sebanyak 4 orang, 3,0\% sebanyak 6 orang, 3,5\% sebanyak 14 orang, 8,0\% sebanyak 16 orang, 9,5\% sebanyak 
19 orang, 11,0\% sebanyak 22 orang, 12,0\% sebanyak 24 orang, 14,0\% sebanyak 28 orang $14,5 \%$ sebanyak 29 orang, sampai jumlah prosentase tertinggi menempati hanya $15,0 \%$ sebanyak 30 orang. Bentuk distribusi di atas dapat diketahui dari grafik Histogram dan kurev normalnya. Dari tampilan grafik di bawah ini dapat dilihat bahwa distrubusi variable item pesan berbentuk tidak normal atau tidak merata. Ini disebabkan oleh faktor jumlah prosentase yang relatif bervariasi.

\section{Histogram}

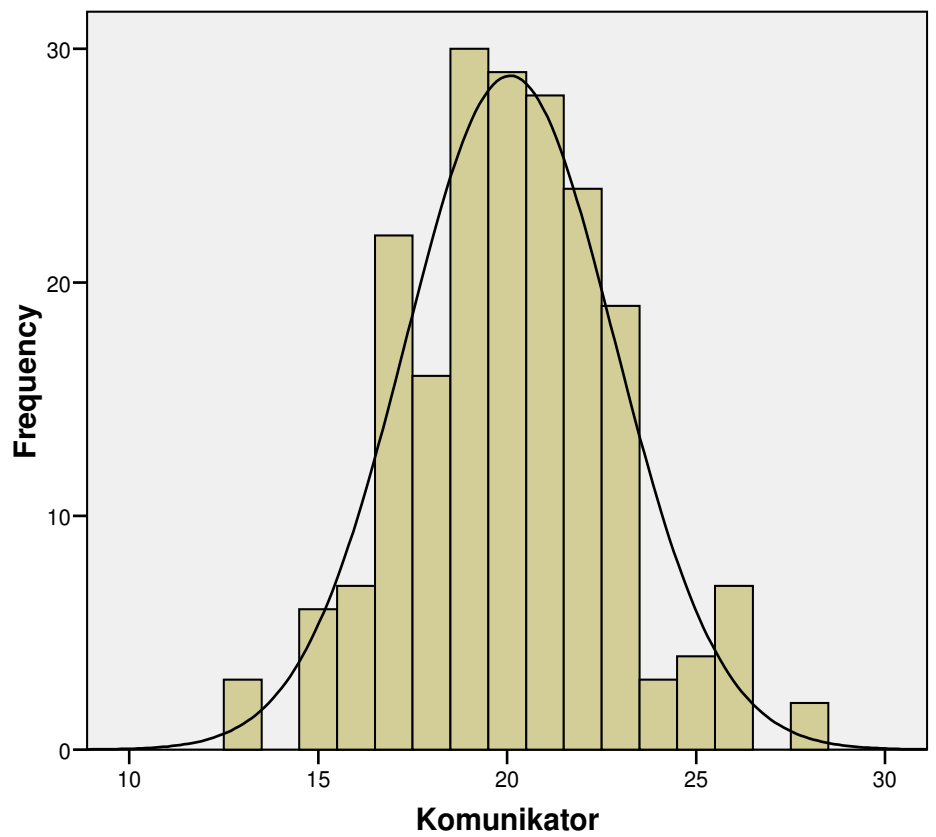

Mean $=20.08$ $\mathrm{N}=200$

\section{Item Pengenalan Komunikator}

Pada Konteks Komunikan/ Pendengar

Questioner pada item pengenalan komunikator pada konteks komunikan/ pendengar diturunkan 7 pertanyaan sebagai identifikasi pokok masalah, di antaranya; Pertama, seorang pengkhotbah perlu mamahami sikon (situasi dan kondisi) pendengarnya. Kedua, seorang pengkhotbah perlu mengetahui latar belakang pendidikan para pendengarnya. Ketiga, seorang pengkhotbah perlu memahami latar belakang hidup keseharian para pendengarnya. Keempat, seorang pengkhotbah perlu memahami keadaan ekonomi dan status sosial para pendengarnya. Kelima, seorang pengkhotbah perlu mengetahui latar belakang budaya (suku) para pendengarnya. Keenam, seorang 
pengkhotbah perlu menyadari adanya perbedaan umur (kaum muda orang tua) di antara pendengarnya. Ketujuh, seorang pengkhotbah perlu mempertimbangkan kapabilitas dan kompetensi di antara pendengarnya.

Tabel 3

Statistik Item Pengenalan Komunikator Pada Konteks Komunikan/Pendengar

\begin{tabular}{|c|c|c|c|c|c|}
\hline & & Frequency & Percent & Valid Percent & $\begin{array}{c}\text { Cumulative } \\
\text { Percent }\end{array}$ \\
\hline Valid & 7 & 1 & ,5 &, 5 & ,5 \\
\hline & 9 & 1 & ,5 & ,5 & 1,0 \\
\hline & 10 & 2 & 1,0 & 1,0 & 2,0 \\
\hline & 11 & 5 & 2,5 & 2,5 & 4,5 \\
\hline & 12 & 4 & 2,0 & 2,0 & 6,5 \\
\hline & 13 & 11 & 5,5 & 5,5 & 12,0 \\
\hline & 14 & 7 & 3,5 & 3,5 & 15,5 \\
\hline & 15 & 9 & 4,5 & 4,5 & 20,0 \\
\hline & 16 & 8 & 4,0 & 4,0 & 24,0 \\
\hline & 17 & 11 & 5,5 & 5,5 & 29,5 \\
\hline & 18 & 13 & 6,5 & 6,5 & 36,0 \\
\hline & 19 & 14 & 7,0 & 7,0 & 43,0 \\
\hline & 20 & 32 & 16,0 & 16,0 & 59,0 \\
\hline & 21 & 41 & 20,5 & 20,5 & 79,5 \\
\hline & 22 & 19 & 9,5 & 9,5 & 89,0 \\
\hline & 23 & 11 & 5,5 & 5,5 & 94,5 \\
\hline & 24 & 5 & 2,5 & 2,5 & 97,0 \\
\hline & 25 & 2 & 1,0 & 1,0 & 98,0 \\
\hline & 27 & 1 & ,5 & ,5 & 98,5 \\
\hline & 28 & 3 & 1,5 & 1,5 & 100,0 \\
\hline & Total & 200 & 100,0 & 100,0 & \\
\hline
\end{tabular}

Distribusi frequency yang ditampilkan menunjukkan jumlah responden terendah, yaitu 1 dengan nilai skor 7 , sampai jumlah responden tertinggi, yaitu 3 dengan nilai skor 28. Pada statistic ini disertai dengan informasi tentang jumlah prosentasenya, responden dengan jumlah persentase dari yang terendah, yaitu 0,5\% sebanyak 3 orang, 1,0\% sebanyak 4 orang, 1,5\% sebanyak 3 orang, 2,0\% sebanyak 4 orang, 2,5\% sebanyak 10 orang, 3,5\% sebanyak 7 orang, 4,0\% sebanyak 8 orang, 4,5\% sebanyak 9 orang, 5,5\% sebanyak 33 orang, 6,5\% sebanyak 13 orang, 7,0\% sebanyak 14 orang, 9,5\% sebanyak 19 orang, 16,0\% sebanyak 32 orang, 
sampai jumlah persentase tertinggi menempati hanya 20,5\% sebanyak 41 orang. Bentuk distribusi di atas dapat diketahui dari grafik Histogram dan kurev normalnya. Dari tampilan grafik di bawah ini dapat dilihat bahwa distribusi variable item pesan berbentuk tidak normal atau tidak merata. Ini disebabkan oleh faktor jumlah prosentase yang relatif bervariasi.

\section{Histogram}

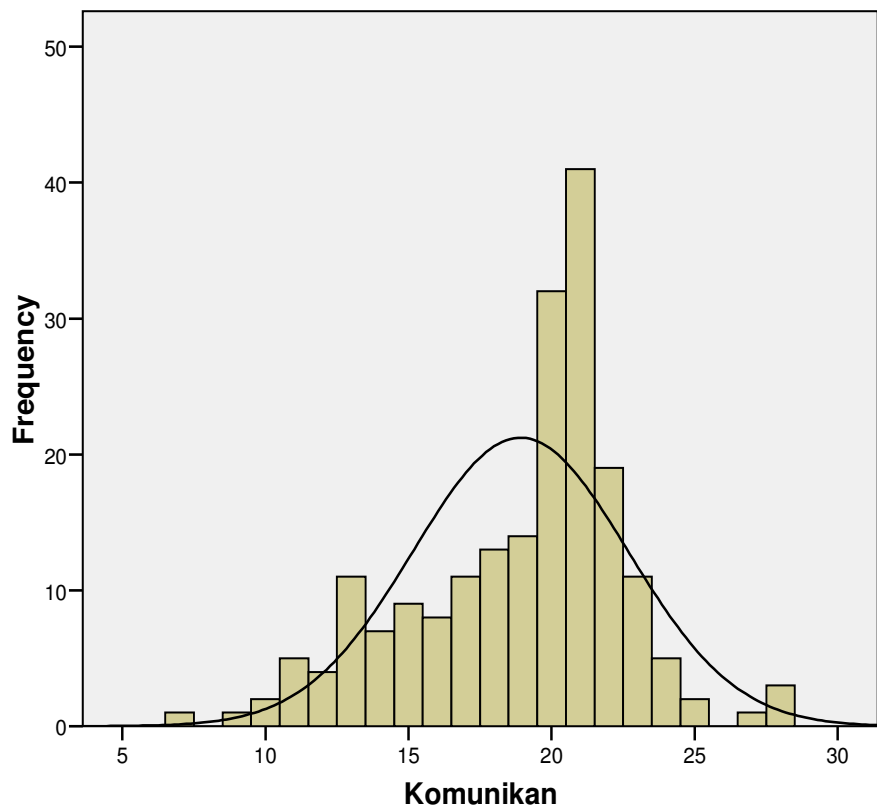

Item Cara Penyampaian

Questioner pada item cara penyampaian diturunkan 7 pertanyaan sebagai identifikasi pokok masalah, di antaranya; Pertama, penyampaian khotbah sedapat-dapatnya terus mengalami inovasi, dan variatif. Kedua, menyampaian khotbah haruslah menggunakan intonasi suara yang bervariasi. Ketiga, khotbah dengan menggunakan alat peraga. Keempat, dalam berkhotbah gerak tubuh haruslah sinkron dengan kata-kata. Kelima, pengkhotbah atau komunikator harus melibatkan pendengarnya. Keenam, menggunakan contoh-contoh yang sederhana, masuk akal dan berdampak bagi pendengarnya. Ketujuh, seorang pengkhotbah atau komunikator berupaya menciptakan terjadinya feedback. 
Tabel 4

Statistik Item Cara Penyampaian

\begin{tabular}{|c|c|c|c|c|c|}
\hline & & Frequency & Percent & $\begin{array}{c}\text { Valid } \\
\text { Percent }\end{array}$ & $\begin{array}{c}\text { Cumulative } \\
\text { Percent }\end{array}$ \\
\hline Valid & 12 & 1 & ,5 & 5 & 5 \\
\hline & 13 & 7 & 3,5 & 3,5 & 4,0 \\
\hline & 14 & 2 & 1,0 & 1,0 & 5,0 \\
\hline & 15 & 3 & 1,5 & 1,5 & 6,5 \\
\hline & 16 & 4 & 2,0 & 2,0 & 8,5 \\
\hline & 17 & 14 & 7,0 & 7,0 & 15,5 \\
\hline & 18 & 10 & 5,0 & 5,0 & 20,5 \\
\hline & 19 & 15 & 7,5 & 7,5 & 28,0 \\
\hline & 20 & 36 & 18,0 & 18,0 & 46,0 \\
\hline & 21 & 33 & 16,5 & 16,5 & 62,5 \\
\hline & 22 & 14 & 7,0 & 7,0 & 69,5 \\
\hline & 23 & 25 & 12,5 & 12,5 & 82,0 \\
\hline & 24 & 18 & 9,0 & 9,0 & 91,0 \\
\hline & 25 & 8 & 4,0 & 4,0 & 95,0 \\
\hline & 26 & 1 & 5 & ,5 & 95,5 \\
\hline & 27 & 2 & 1,0 & 1,0 & 96,5 \\
\hline & 28 & 7 & 3,5 & 3,5 & 100,0 \\
\hline & Total & 200 & 100,0 & 100,0 & \\
\hline
\end{tabular}

Distribusi frequency yang ditampilkan menunjukkan jumlah responden terendah, yaitu 1 dengan nilai skor 12 , sampai jumlah responden tertinggi, yaitu 7 dengan nilai skor 28. Pada statistic ini disertai dengan informasi tentang jumlah prosentasenya, responden dengan jumlah persentase dari yang terendah, yaitu 0,5\% sebanyak 2 orang, 1,0\% sebanyak 4 orang, 1,5\% sebanyak 3 orang, 2,0\% sebanyak 4 orang, 3,5\% sebanyak 14 orang, 4,0\% sebanyak 8 orang, 5,0\% sebanyak 10 orang, 7,0\% sebanyak 28 orang, $7,5 \%$ sebanyak 15 orang, 9,0\% sebanyak 18 orang, $12,5 \%$ sebanyak 25 orang, $16,5 \%$ sebanyak 33 orang, sampai jumlah prosentase tertinggi menempati hanya $18,0 \%$ sebanyak 36 orang. Bentuk distribusi di atas dapat diketahui dari grafik Histogram dan kurev normalnya. Dari tampilan grafik di bawah ini dapat dilihat bahwa distrubusi variable item pesan berbentuk tidak normal atau tidak merata. Ini disebabkan oleh faktor jumlah prosentase yang relatif bervariasi. 


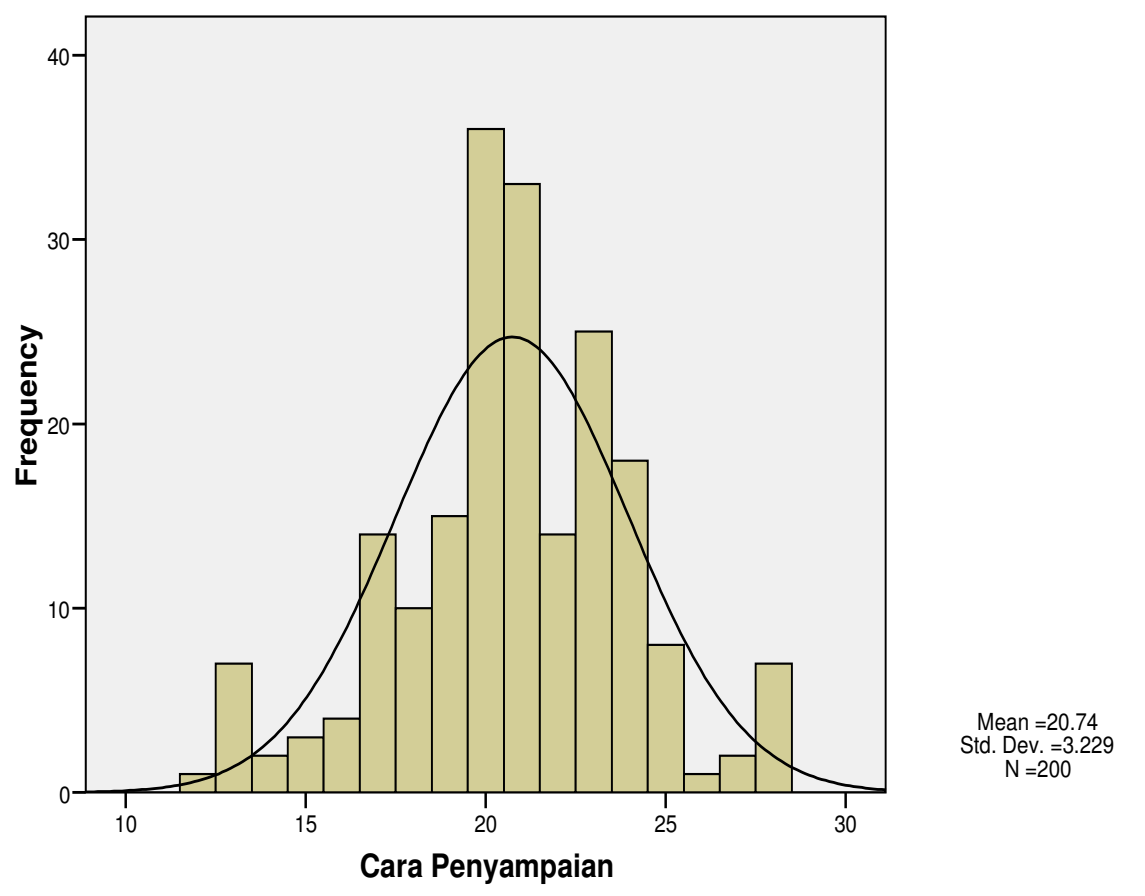

\section{Item Hasil}

Questioner pada item hasil diturunkan 7 pertanyaan sebagai identifikasi pokok masalah, di antaranya; Pertama, mendorong pendengarnya untuk berbuat seperti yang dikehendaki oleh Firman Tuhan. Kedua, dapat memotivasi jemaat untuk aktif dalam ibadahibadah di gereja ataupun di rumah tangga. Ketiga, dapat menolong jemaat menjadi saksi atau kesaksian bagi orang lain. Keempat, dapat menyatakan untuk meningalkan hidup lama dalam mengalami lahir baru. Kelima, dapat mendorong jemaat untuk mengambil keputusan dalam perubahan sikap. Keenam, dapat memotivasi jemaat agar bertumbuh dalam iman dan memiliki hubungan pribadi yang semakin dekat dengan Tuhan. Ketujuh, dapat mewujudkan Jemaat yang mengalami pertumbuhan, baik secara kuantitas maupun secara kualitas. 
Tabel 5

Statistik Item Hasil

\begin{tabular}{|ll|r|r|r|r|}
\hline & & & Valid \\
& & Frequency & Percent & Cumulative \\
Percent & Percent \\
\hline Valid & 15 & 2 & 1,0 & 1,0 & 1,0 \\
& 16 & 1 &, 5 &, 5 & 1,5 \\
& 17 &, 5 &, 5 & 2,0 \\
18 & 2 & 1,0 & 1,0 & 3,0 \\
19 & 4 & 2,0 & 2,0 & 5,0 \\
20 & 5 & 2,5 & 2,5 & 7,5 \\
21 & 62 & 31,0 & 31,0 & 38,5 \\
22 & 12 & 6,0 & 6,0 & 44,5 \\
23 & 22 & 11,0 & 11,0 & 55,5 \\
24 & 14 & 7,0 & 7,0 & 62,5 \\
25 & 11 & 5,5 & 5,5 & 68,0 \\
26 & 15 & 7,5 & 7,5 & 75,5 \\
27 & 18 & 9,0 & 9,0 & 84,5 \\
& 31 & 15,5 & 15,5 & 100,0 \\
& 20 & 100,0 & 100,0 & \\
\hline
\end{tabular}

Distribusi frequency yang ditampilkan menunjukkan jumlah responden terendah, yaitu 2 dengan nilai skor 15, sampai jumlah responden tertinggi, yaitu 31 dengan nilai skor 28. Pada statistic ini disertai dengan informasi tentang jumlah prosentasenya, responden dengan jumlah prosentase dari yang terendah, yaitu 0,5\% sebanyak 2 orang, 1,0\% sebanyak 4 orang, 2,0\% sebanyak 4 orang, 2,5\% sebanyak 5 orang, 5,5\% sebanyak 11 orang, 6,0\% sebanyak 12 orang, 7,0\% sebanyak 14 orang, 7,5\% sebanyak 15 orang, 9,0\% sebanyak 18 orang, $11,0 \%$ sebanyak 22 orang, 15,5\% sebanyak 31 orang, sampai jumlah persentase tertinggi menempati hanya 31,0\% sebanyak 62 orang. Bentuk distribusi di atas dapat diketahui dari grafik Histogram dan kurev normalnya. Dari tampilan grafik di bawah ini dapat dilihat bahwa distribusi variabel item pesan berbentuk tidak normal atau tidak merata. Ini disebabkan oleh faktor jumlah prosentase yang relatif bervariasi. 


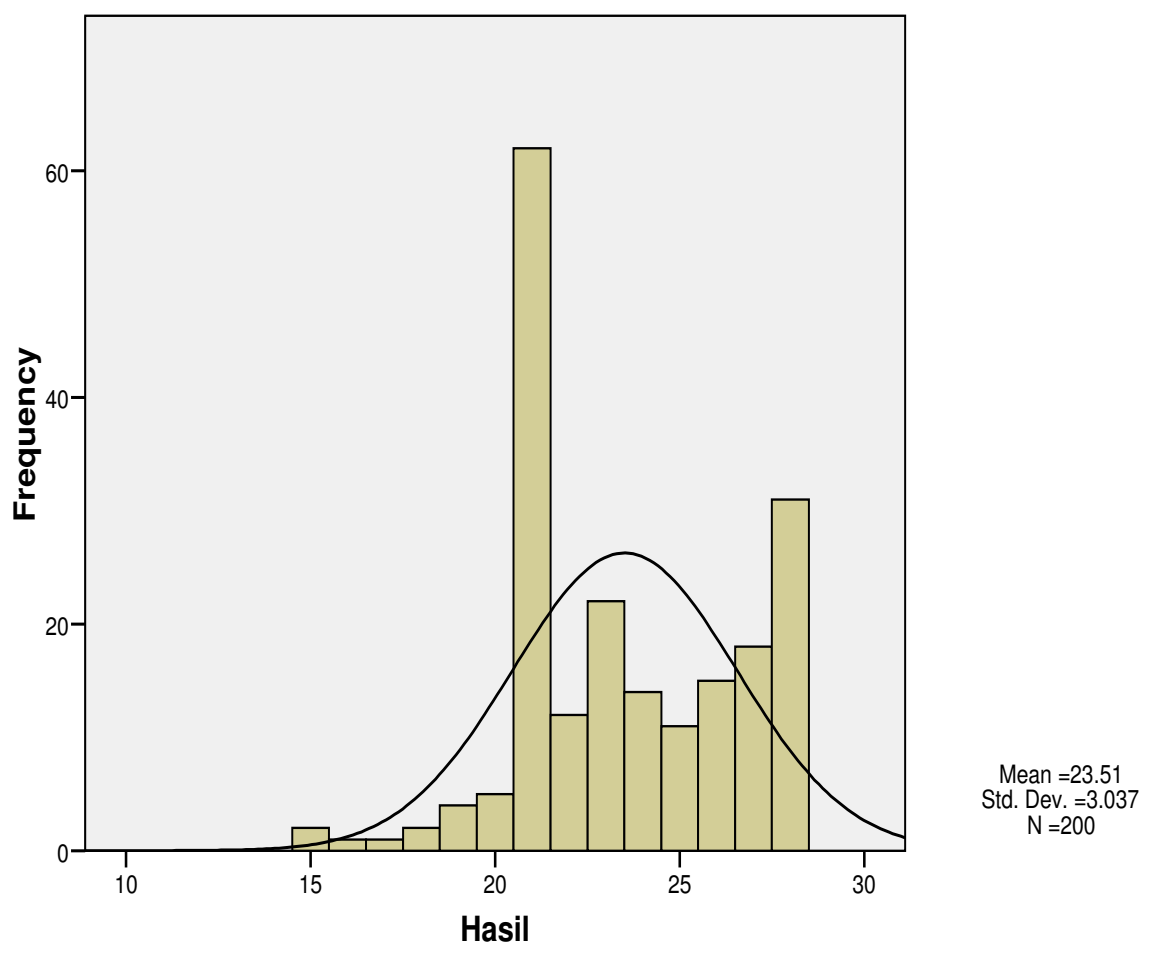

\section{Item Respon Terhadap Arus Balik (Feedback)}

Questioner pada item respon terhadap arus balik (feedback) diturunkan 7 pertanyaan sebagai identifikasi pokok masalah, di antaranya; Pertama, seorang pengkhotbah perlu melibatkan pendengarnya untuk mengajukan pendapat atau sanggahan yang logis berdasarkan teks atau konteks yang telah dibacakan. Kedua, seorang pengkhotbah memberikan kesempatan kepada komunikan untuk berbicara atau berkomentar dalam suasana berkhotbah. Ketiga, seorang pengkhotbah perlu mengajukan pertanyaan-pertanyaan atau komentar yang bertujuan agar terjadi arus balik (feedback) dalam berkhotbah. Keempat, umpan balik (feedback) dapat dilakukan dalam suasana ibadah. Kelima, untuk merespon umpan balik (feedback) dapat dilakukan setelah rangkaian ibadah telah selesai. Keenam, pendengar (jemaat) yang mengajukan keberatannya karena tidak setuju secara logika kepada seorang pengkhotbah, dalam suasana berkhotbah. Ketujuh, balik (feedback) bisa terjadi kapan saja. Bisa terjadi pada hari yang sama (saat berkhotbah), bisa terjadi di hari-hari berikutnya (tanpa batas waktu). 
Tabel 6

Statistik Item Respon Terhadap Arus Balik (Feedback)

\begin{tabular}{|rl|r|r|r|r|}
\hline & & & \multicolumn{1}{|c|}{$\begin{array}{c}\text { Valid } \\
\text { Percent }\end{array}$} & $\begin{array}{c}\text { Cumulative } \\
\text { Percent }\end{array}$ \\
\hline Valid & 7 & Frequency & Percent & Percer \\
& 8 & 1 &, 5 &, 5 &, 5 \\
& 2 & 1,0 & 1,0 & 1,5 \\
& 13 & 6,5 & 6,5 & 8,0 \\
& 11 & 9 & 4,5 & 4,5 & 12,5 \\
12 & 23 & 11,5 & 11,5 & 24,0 \\
13 & 16 & 8,0 & 8,0 & 32,0 \\
14 & 19 & 9,5 & 9,5 & 41,5 \\
15 & 30 & 15,0 & 15,0 & 56,5 \\
16 & 21 & 10,5 & 10,5 & 67,0 \\
17 & 13 & 6,5 & 6,5 & 73,5 \\
18 & 20 & 10,0 & 10,0 & 83,5 \\
19 & 11 & 5,5 & 5,5 & 89,0 \\
20 & 11 & 5,5 & 5,5 & 94,5 \\
21 & 2 & 1,0 & 1,0 & 95,5 \\
22 & 2 & 1,0 & 1,0 & 96,5 \\
23 & 2 & 1,0 & 1,0 & 97,5 \\
24 & 1 &, 5 &, 5 & 98,0 \\
26 & 1 &, 5 &, 5 & 98,5 \\
28 & 1 &, 5 &, 5 & 99,0 \\
Total & 2 & 1,0 & 1,0 & 100,0 \\
& & 100,0 & 100,0 & \\
\hline
\end{tabular}

Distribusi frequency yang ditampilkan menunjukkan jumlah responden terendah, yaitu l dengan nilai skor 12, sampai jumlah responden tertinggi, yaitu 7 dengan nilai skor 28. Pada statistic ini disertai dengan informasi tentang jumlah prosentasenya, responden dengan jumlah prosentase dari yang terendah, yaitu 0,5\% sebanyak 4 orang, 1,0\% sebanyak 10 orang, 4,5\% sebanyak 9 orang, 5,5\% sebanyak 22 orang, 6,5\% sebanyak 26 orang, 8,0\% sebanyak 16 orang, 9,5\% sebanyak 19 orang, $10,0 \%$ sebanyak 20 orang, $10,5 \%$ sebanyak 21 orang, $11,5 \%$ sebanyak 23 orang, sampai jumlah prosentase tertinggi menempati hanya $15,0 \%$ sebanyak 30 orang. Bentuk distribusi di atas dapat diketahui dari grafik Histogram dan kurev normalnya. Dari tampilan grafik di bawah ini dapat dilihat bahwa distribusi variable item pesan berbentuk tidak normal atau tidak merata. Ini disebabkan oleh faktor jumlah prosentase yang relatif bervariasi. 
Histogram

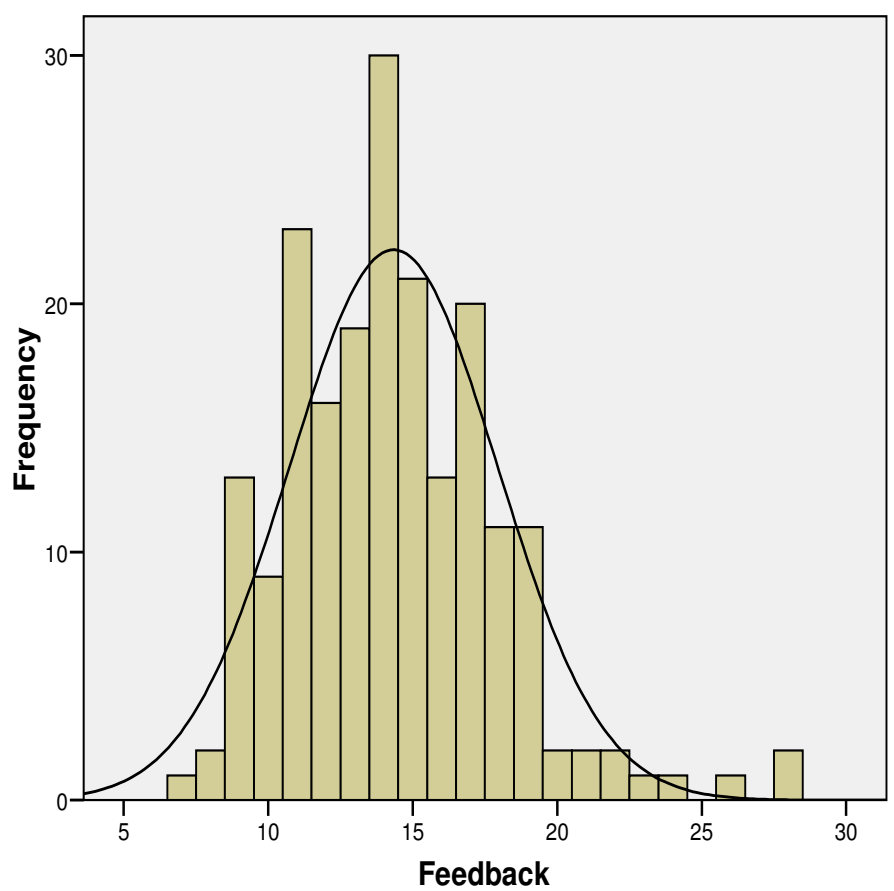

Mean $=14.34 \square$
Std. Dev. $=3.598$ $\mathrm{N}=200$ 


\section{Analisis Data}

Penyajian data yang memuat pemaparan dan perhitungan data telah dilakukan. Tahap selanjutnya adalah menganalisis data untuk mendapatkan hasil yang objektif dan optimal, dijelaskan sebagai berikut:

Tabel 7

Regresi (Coefficients)

\begin{tabular}{|c|c|c|c|c|c|c|}
\hline \multicolumn{2}{|c|}{ Model } & \multirow{2}{*}{\multicolumn{2}{|c|}{$\begin{array}{l}\text { Unstandardized } \\
\text { Coefficients } \\
\begin{array}{c|c}\text { Btd. } \\
\text { B } & \text { Error }\end{array}\end{array}$}} & \multirow{2}{*}{$\begin{array}{c}\text { Standa } \\
\text { rdized } \\
\text { Coeffici } \\
\text { ents } \\
\text { Beta }\end{array}$} & \multirow{2}{*}{ t } & \multirow{2}{*}{$\begin{array}{l}\text { Sig. } \\
\text { Std. } \\
\text { Error }\end{array}$} \\
\hline & & & & & & \\
\hline \multirow[t]{6}{*}{1} & \multirow{2}{*}{$\begin{array}{l}\text { (Constant) } \\
\text { Pesan }\end{array}$} & 18,207 & 2,233 & & 8,153 & ,000 \\
\hline & &,- 081 & ,074 &,- 083 & $\begin{array}{r}1,087 \\
\end{array}$ & ,278 \\
\hline & \multirow{2}{*}{$\begin{array}{l}\text { Komunikator } \\
\text { Komunikan }\end{array}$} & , 142 & ,080 & , 130 & 1,786 & ,076 \\
\hline & &,- 085 & ,060 &,- 105 & 1,423 & , 156 \\
\hline & $\begin{array}{l}\text { Cara } \\
\text { Penyampaian }\end{array}$ & ,256 &, 070 & ,272 & 3,673 & ,000 \\
\hline & Feedback &, 043 & ,062 &, 051 & ,695 & 488 \\
\hline
\end{tabular}

a Dependent Variable: Hasil

Rumus persamaan regresi untuk k prediktor

$$
\mathrm{Y}^{\prime}=\mathrm{a}+\mathrm{blXl}+\mathrm{b} 2 \mathrm{X} 2+\ldots+\mathrm{bk} \mathrm{Xk}
$$

Keterangan:

$\mathrm{Y}^{\prime} \quad=$ nilai yang diprakirakan

a $\quad=y$-intercept (banyaknya Y bila $\mathrm{X}=0$ )

$\mathrm{b}=$ slope of regretion line (seberapa banyak $\mathrm{Y}$ bervariasi dengan suatu peningkatan suatu unit $X$ )

$\mathrm{X} \quad=$ nilai yang memperkirakan

$\mathrm{k} \quad$ = banyaknya kelompok

Aplikasi perhitungan analisis regresi dalam penelitian ini, $\mathrm{Y}$ adalah variabel Item hasil, bl adalah Item Pesan, b2 adalah item konteks komunikator, b3 adalah pengenalan komunikator pada konteks komunikan, b4 item capa penyampaian, b5 item respon terhadap arus balik (Feedback), dituliskan demikian:

$$
Y^{\prime}=8,153+(1,087)+1,786+(1,423)+3,673+, 695
$$


Dari persamaan ini berarti, berbanding terbalik apabila nilai pesan tinggi nilai pesan kurang $(-1,087)$, sebaliknya nilai pesan rendah nilai akan tinggi. Semakin tinggi nilai komunikator $(1,786)$, semakin tinggi juga nilai hasil. Nilai komunikan rendah $(-1,423)$ namun nilai cara penyampaian $(3,673)$ merupkan nilai tertinggi, sementara nilai feedback $(, 695)$ rendah, namun bukan nilai minus.

\section{Penghitungan dan Nilai Data}

Hasil prosentase angket yang disebarkan kepada Jemaat dan Gembala Sidang Gereja KIBAID Klasis Makassar, terdiri atas jawaban sangat setuju, setuju, kurang setuju, dan tidak setuju, yang berdiri secara terpisah. Sangat setuju lebih baik daripada setuju. Setuju lebih baik daripada kurang setuju. Kurang setuju lebih baik daripada tidak setuju. Oleh karena itu, setiap jawaban masing-masing diberi nilai, sangat setuju bernilai 4, setuju bernilai 3, kurang setuju bernilai 2, dan tidak setuju bernilai 1.

\section{Uraian Pesan/Khotbah}

Berdasarkan jumlah dan nilai skor responden, ditemukan bahwa hasil penilaian pada item pesan/khotbah dinyatakan dalan bentuk prosentase menunjukkan angka $82,30 \%$ dalam perhitungan $100 \%$ pada item pesan, sedangkan perhitungan secara menyeluruh (100\% untuk semua item), maka hasil yang ditemukan menunjukkan angka 13,71\%.

Angka-angka ini menunjukkan bahwa, sejauh ini responden masih memberikan apresiasi yang cukup baik terhadap pesan/khotbah. Jemaat secara keseluruhan masih menginginkan pesan Firman Tuhan yang disampaikan melalui khotbah haruslah merupakan pesan yang bersumber dari Alkitab. jemaat atau pendengar juga masih sangat menginginkan uraian Firman Tuhan itu didasarkan pada teks atau konteks Firman Tuhan yang telah dipersiapkan dan dibacakan pada saat khotbah berlangsung.

Jemaat atau pendengar mengharapkan pesan Firman Tuhan yang disampaikan melalui khotbah, merupakan pesan yang dapat dipahami oleh semua kalangan, tidak hanya kepada orang-orang tertentu saja, pesannya universal, relevan dan sesuai dengan kebutuhan pendengarnya. Dalam menyampaikan pesan Firman Tuhan, jemaat atau pendengar juga menginginkan pesan yang sesuai dengan perkembangannya, pesan yang selalu aktual, disesuaikan dengan situasi dan kondisi jemaat, dan juga disesuaikan dengan hari-hari besar gerejawi.

Pada saat menyampaikan pesan Firman Tuhan, jemaat atau pendengar mengharapkan seseorang yang menyampaikan pesan itu tidak menyombongkan diri, tidak pilih kasih, mengganggap sesorang lebih 
tinggi atau lebih penting dari yang lain. Jemaat atau pendengar juga menginginkan bahwa pesan khotbah itu juga terus mengalami perubahan dan kemajuan sebagaimana ilmu pengetahuan mengalami kemajuan dan perubahan.

\section{Uraian Konteks Komunikator/Sumber}

Berdasarkan jumlah dan nilai skor responden, ditemukan bahwa hasil penilaian pada item konteks komunikator/sumber dinyatakan dalan bentuk prosentase menunjukkan angka $71,71 \%$ dalam perhitungan $100 \%$ pada item konteks komunikator/sumber, sedangkan perhitungan secara menyeluruh (100\% untuk semua item), maka hasil yang ditemukan menunjukkan angka 11,95\%.

Angka-angka ini menunjukkan bahwa, sejauh ini responden masih memberikan apresiasi yang cukup baik terhadap konteks komunikator sebagai sumber. Sebagian besar jemaat masih sangat mengharapkan bahwa orang-orang yang terlibat dalam pelayanan berkhotbah adalah mereka yang telah mendapatkan panggilan khusus dari Tuhan dan bersedia untuk melayani Dia. Selain itu sebagaimana yang diharapkan sebelumnya, bahwa pesan khotbah dijelaskan berdasarkan teks atau konteks Firman Tuhan yang telah dibacakan, dalam hal ini pun jemaat atau pendengar mengharapkan dari seorang komunikator Firman Tuhan untuk tetap fokus pada teks yang ia telah bacakan. Hal ini bisa saja terjadi, karena beberapa pengalaman mereka dalam mengikuti/menyimak khotbah-khotbah pendeta dan gembala sidang yang kadang-kadang menyimpang dari teks atau tidak fokus pada teks yang baru saja ia bacakan untuk dikhotbahkan.

Pada uraian konteks komunikator sebagai sumber, sebagai jemaat atau pendengar mengharapkan seorang pengkhotbah itu adalah seorang yang telah mengenal dengan baik jemaatnya, seorang yang terus mau belajar dan meningkatkan kemampuannya dalam hal kerohanian dan penguasaan ilmu pengetahuan melalui belajar dan membaca. Dalam hubungan sosial, jemaat atau pendengar mengharapkan seorang pengkhotbah itu adalah seorang yang mempunyai kemampuan untuk berkomunikasi kepada lingkungan dan masyarakat di mana ia berada. Lebih khusus lagi, jalinan hubungan komunikasi yang baik dengan jemaat atau pendengarnya.

Berkaitan dengan tugas dan tanggungjawab, sebenarnya jemaat juga sangat menginginkan seorang pengkhotbah adalah seorang yang profesional dalam berkhotbah. Bagaimana seharusnya dan baiknya berkhotbah atau menyampaikan Firman Tuhan kepada jemaat agar jemaat bertumbuh, mengalami pemulihan, agar jemaat merasa senang dalam mengaktualiasikan imannya kepada orang lain. 
Tuntutan pada seorang pengkhotbah yang haruslah berlatar belakang atau berasal dari suku yang sama, mendapatkan tanggapan yang bervariasi, sebagian jemaat atau pendengar sependapat bahwa seorang pengkhotbah haruslah berasal dari suku yang sama dengan komunikannya, namun sebagian orang juga tidak menginginkan hal itu. Ini terlihat jelas pada jawaban responden yang cukup bervariasi.

\section{Uraian Pengenalan Komunikator pada Konteks Komunikan}

Berdasarkan jumlah dan nilai score responden, ditemukan bahwa hasil penilaian pada item pengenalan komunikator pada konteks komunikan dinyatakan dalan bentuk prosentase menunjukkan angka $67,55 \%$ dalam perhitungan $100 \%$ pada item pengenalan komunikator pada konteks komunikan, sedangkan perhitungan secara menyeluruh (100\% untuk semua item), maka hasil yang ditemukan menunjukkan angka $11,25 \%$.

Angka-angka ini menunjukkan bahwa, sejauh ini responden masih memberikan apresiasi yang masih dianggap baik (karena masih diatas $50 \%$ untuk perhitungan lokal) terhadap pengenalan komunikator pada konteks komunikan. Sebagian jemaat sangat setuju apabila seorang komunikator Firman Tuhan atau pengkhotbah dalam mempersiapkan materi khotbahnya perlu mengetahui situasi dan kondisi dari pendengarnya. Latar belakang dari keseharian atau hidup sehari-hari komunikannya, agar pesan tidak melenceng jauh dari keadaan dan kebutuhan komunikannya. Perlu mempertimbangkan juga latar belakang pendidikan komunikannya, agar pesan yang disampaikan dapat dimengerti dan dipahami oleh semua kalangan. Mengetahui kondisi sosial ekonomi juga perlu dipertimbangkan dalam berkhotbah, agar khotbah itu menjadi berkat, dan menumbuhkan cinta kasih dan persaudaraan di antara komunikannya. Atas hal-hal ini, sebagian jemaat lagi memberi apresiasi dan jawabannya yang bervariasi.

Dari sudut pandang latar belakang kebudayaan, pengenalan komunikator pada komunikan, sebagian jemaat atau pendengar menginginkan agar seorang komunikator Firman Tuhan perlu mengetahui hal itu, sehingga istilah-istilah yang dipakai atau bahasa yang digunakan tidak salah dalam penggunaannya. Di samping itu seorang komunikator juga diharapkan untuk memahami kondisi di mana ia berkhotbah, kepada siapa khotbah itu disampaikan, karena dalam setiap ibadah tempat khotbah disampaikan tentu komunikannya ada orang tua dan ada juga yang anak muda.

Seorang pengkhotbah yang diharapkan oleh jemaat, adalah seorang yang dapat menyadari persis kapabilitas dan kompetensi setiap orang sebagai komunikannya. Pengkhotbah yang jeli melihat akan hal ini, akan 
bersikap arif, mana di antara kapabilitas dan kompetensi yang dapat diberdayakan dan mana yang dianggap menyimpang perlu diperbaiki.

\section{Uraian Cara Penyampaian}

Berdasarkan jumlah dan nilai skor responden, ditemukan bahwa hasil penilaian pada item cara penyampaian dinyatakan dalan bentuk prosentase menunjukkan angka $74,05 \%$ dalam perhitungan $100 \%$ pada item cara penyampaian, sedangkan perhitungan secara menyeluruh (100\% untuk semua item), maka hasil yang ditemukan menunjukkan angka $12,34 \%$.

Angka-angka ini menunjukkan bahwa, sejauh ini responden masih memberikan apresiasi yang cukup baik terhadap cara penyampaian. Masin-masing pengkhotbah mungkin memiliki cara yang berbeda-beda dalam menyampaikan khotbah. Ada yang membangun kesan kesakralan, tegang, santai, dan humoris, namun dalam cara penyampaian khotbah jemaat atau pendengar mengharapkan cara penyampaian khotbah terus mengalami inovasi dan cara-cara yang variatif dalam menyampaikan khotbah. Dalam penggunaan intonasi suara, juga perlu diperhatikan bagi seorang pengkhotbah, karena jemaat sangat menginginkan untuk seorang pengkhotbah yang dapat mengatur penggunaan waktunya, bagiamana yang perlu berbicara lembut, dan dibagiamana nada suara harus diperbesar atau ditegaskan.

Pada bagian yang lain, misalnya pada bidang membangun daya pikat, perhatian, konsentrasi, sebagian besar jemaat atau pendengar sependapat bahwa seorang pengkhotbah itu perlu menggunakan alat peraga sebagai media yang sangat membantu semua itu. Menggunakan contoh-contoh yang sederhana, masuk akal, namun memberi dampak atau pengaruh yang baik bagi jemaatnya. Kata-kata yang disampaikan oleh seorang pengkhotbah jemaat atau pendengar menginginkan agar penggunaannya selalu sinkron dengan kata-kata, hal ini bisa menjadi suatu keinginan sekaligus menjadi kritik yang membangun bagi para pengkhotbah, banyak pengkhotbah yang perhatian dan pandangannya hanya pada satu arah, kalau bukan pada jam dinding, selalu mengarah kearah plafon gereja. Tubuh dan tangannya susah digerakkan.

Berdasarkan cara penyampaian, untuk mencapai tujuan khotbah yang komunikatif kelihatannya menjadi hal yang sulit dilakukan, berdasarkan jawaban responden. Jemaat atau pendengar masih belum bersedia bahwa dalam khotbah, atau dalam situasi berkhotbah pendengarnya perlu dilibatkan. Juga pada dukungan untuk memberi peluang kepada komunikator dalam upayanya menciptakan feedback dalam suasana berkhtobah. 


\section{Uraian Hasil}

Berdasarkan jumlah dan nilai skor responden, ditemukan bahwa hasil penilaian pada item hasil dinyatakan dalan bentuk prosentase menunjukkan angka 83,96\% dalam perhitungan 100\% pada item hasil, sedangkan perhitungan secara menyeluruh (100\% untuk semua item), maka hasil yang ditemukan menunjukkan angka 13,99\%.

Angka-angka ini menunjukkan bahwa, sejauh ini responden masih memberikan apresiasi yang cukup baik terhadap hasil. Jemaat atau pendengar memberi dukungan penuh bahwa melalui penyampaian Firman Tuhan, mereka mendapatkan dorongan dan kekuatan untuk berbuat seperti yang dikehendaki oleh Firman Tuhan. Juga dapat memberi motivasi yang positif kepada jemaat, agar mereka dapat tetap aktif atau bahkan labih aktif lagi mengikuti ibadah-ibadah, baik yang dilakukan di gereja (setiap minggu) maupun dalam ibadah-ibadah rumah tangga, juga aktif dalam pelayanan.

Hasil yang diharapkan ketika Firman telah selesai disampakan oleh jemaat atau pendengar ialah mereka menginginkan agar firman Tuhan itu dapat menyentuh kebutuhan hidupnya, menyentuh hatinya, agar setiap jemaat mendapatkan pemulihan, bersedia meninggalkan kehidupan yang lama dan menjalani kehidupan yang baru, kehidupan yang dekat dengan Tuhan, dan kehidupan yang dapat menjadi saksi, kesaksian bagi orang lain. Agar melalui hidupnya itu, orang lain dapat mengenal dan menerima Yesus sebagai Tuhan dan juruselamatnya secara pribadi.

\section{Uraian Respon Terhadap Arus Balik (Feedback)}

Berdasarkan jumlah dan nilai score responden, ditemukan bahwa hasil penilaian pada item respon terhadap arus balik (feedback) dinyatakan dalan bentuk prosentase menunjukkan angka 51,19\% dalam perhitungan 100\% pada item respon terhadap arus balik (feedback), sedangkan perhitungan secara menyeluruh (100\% untuk semua item), maka hasil yang ditemukan menunjukkan angka 8,58\%.

Angka-angka ini menunjukkan, bahwa sejauh ini responden masih memberikan apresiasi yang masih dapat dikatakan, baik terhadap respon terhadap arus balik atau (feedback). Masih dapat dikatakan baik karena melalui penilaian responden prosentasenya masih di atas 50\% atau lebih dari setengahnya, yaitu $51,19 \%$. Item feedback sangat didukung oleh jemaat atau pendengar dengan status pendidikan strata 2, nilai prosentasenya sebesar $88,83 \%$ berdasarkan penghitungan nilai respondennnya, disusul oleh jemaat atau pendengar dengan status pendidikan SMU dan sederajat, yaitu 51,13\%. Kemudian mereka yang berstatus pendidikan strata l dengan nilai prosentase 49,58\%. 
Yang menjadi harapan di balik respon terhadap arus balik atau feedback itu meliputi, seorang pengkhotbah melibatkan pendengar atau komunikannya dalam berkhotbah, misalnya pada pengajuan pertanyaanpertanyaan siapa, kapan, di mana, mengapa dan bagaimana. Atau pada skala yang lebih besar, keterlibatan ini mencakup pengajuan pendapat atau sanggahan yang logis dalam khotbah berdasarkan teks atau konteks Firman Tuhan yang sedang dibahas. Seorang pengkhotbah memberi kesempatan kepada komunikannya untuk berbicara atau berkomentar dalam suasana berkhotbah, misalnya kesempatan untuk menyampaikan sedikit kesaksian bagaimana Tuhan bekerja dalam hidupnya, tentu yang sangat berkaitan dengan khotbah. Seorang pengkhotbah juga diharapkan untuk "memancing" jemaat atau pendengarnya dengan pertanyaan-pertanyaan dengan tujuan terjadi arus balik dalam sebagai bagian dari komunikasi berkhotbah. Misalnya dengan bertanya, mengapa kira-kira itu terjadi?, Bagaimana itu bisa terjadi?, Apa pengaruhnya untuk kehidupan kekristenan pada masa kini?

Bila sebagian jemaat atau pendengar mengharapkan feedback itu tidak terjadi dalam suasana berkhotbah. Juga terdapat jemaat atau pendengar yang mengharapakan feedback dapat dilakukan setelah seluruh rangkaian ibadah telah selesai. Feedback bisa terjadi di ruang majelis atau ruang doa dan bisa antarpribadi maupun secara kelompok. Feedback yang terjadi secara kelompok, ini memungkinkan terjadinya follow up dalam bentuk kelompok. Dan kelompok-kelopok ini akan menjadi kelompk diskusi yang akan sangat menarik. Apabila terjadi hal seperti ini, pertanda bahwa gereja atau persekutuan rohani itu mengalami kemajuan dan pertumbuhan (pada ruang lingkup yang berbeda). Selain feedback terjadi setelah ibadah, ada juga yang sangat mengharapkan feedback dapat terjadi kapan saja dan di mana saja (dalam jangka waktu yang tidak ditentukan). Kemungkinan ini kisa terjadi, bilamana pengkhotbah secara tidak disengaja bertemu dengan jemaat atau pengdengarnya di pesawat, di bus, atau di tempat-tempat pertemuan lainnya, kemudian jemaat itu mengatakan, "Khotbah bapak/ibu beberapa waktu yang lalu, itu sangat menarik" kemudian terjadilah diskusi diantara mereka.

Feedback dapat terjadi dalam bentuk dan dengan cara apa saja. Secara verbal seperti yang dimaksudkan di atas, secara nonverbal dapat diwujutkan melalui tindakan seperti anggukan kepala, menggelangkan kepala, menagis, terawa, maju memenuhi panggilan altarcall, memberi persembahan, dan lain sebagainya. Demikianlah feedback yang diharapkan dalam berkhotbah. 


\section{PENUTUP}

\section{Kesimpulan}

Dari bahasan tersebut dapat ditarik beberapa kesimpulan sebagai berikut: Pertama, untuk mencapai tujuan khotbah yang komunikatif dalam jemaat, harus memperhatikan unsur-unsur komunikasi. Unsurunsur ini harus dapat bersinergi, seperti pada peran pesan, peran komunikator, peran komunikan, peran cara menyampaikan, peran hasil, dan peran feedback. Kedua, Pesan dalam khotbah merupakan pesan yang bersumber dari Allah yang didapatkan/dibaca lewat Alkitab. Pesan disampaikan untuk manusia sesuai dengan kebutuhannya, bukan berdasarkan kemauan atau keinginan pengkhotbahnya. Ketiga, komunikator atau seorang pengkhotbah adalah orang yang mendapat panggilan khusus menjadi seorang pengkhotbah. Seorang yang mampu menyampaikan pesan Firman Tuhan secara arif dan profesional, agar jemaat atau komunikan dapat mengalami hidup yang penuh dengan kataatan kepada Tuhan. Keempat, komunikator atau seorang pengkhotbah harus mengetahui siapa dan bagaimana komunikannya itu. Setiap komunikan mempunyai kebutuhan dan keinginan yang berbedabeda, komunikan juga mempunyai kelebihan dan kekurangan masingmasing, dan dari semua perbedaan itu setiap orang ingin kebutuhankebutuahannya tercukupi. Kelima, cara menyampaikan menjadi salah satu faktor penentunya. Cara-cara yang digunakan harus mengalami pembaruan, penggunaan ekspresi tubuh dan kata-kata yang tepat, pengunaan alat peraga. Keenam, khotbah yang memberi efek rohani bagi jemaat ialah khotbah yang dapat menolong, mendorong dan memotivasi jemaatnya untuk mengalami kemajuan hidup dan rohani. Khotbah yang dapat menobatkan, dan membuat jemaat mau untuk meninggalkan kehidupan yang lama kemudian menjalani hidup baru yang lebih dekat kepada Tuhan. Ketujuh, menjadi tolak ukur terakhir (dalam penelitian ini) untuk mencapai tujuan khotbah yang komunikatif ialah terjadinya feedback. Melalui feedback seorang komunikator dapat mengetahui seberapa jauh perkembangan dan kemajuan rohani yang ada pada jemaat atau pendengarnya.

\section{Saran-Saran}

Pertama, bagi hamba-hamba Tuhan, agar lebih meningkatkan gairah jemaat untuk mendengar firman Tuhan melalui cara-cara berkhotbah yang lebih menarik, hidup, dan komunikatif. Ketiga, hamba Tuhan dengan rendah hati dapat menerima kritik dan saran dari jemaat manakala dalam hal menyampaikan Firman Tuhan, mungkin ada yang 
perlu dikoreksi, dibenahi, dikurangi atau diperbarui. Keempat, bagi jemaat agar kritis dan selektif dalam memberikan pujian, sanjungan, atau koreksi pada khotbah-khorbah yang disampaikan oleh hamba Tuhan. Tentu agar semuanya sesuai yang diharapkan dan nama Tuhan yang dimuliakan. Kelima, jemaat pun perlu dan dapat belajar bagaimana cara membuat atau menyampaikan khotbah, dengan demikian jemaat dapat merasakan beratnya tugas dan tanggung jawab menjadi seorang pengkhotbah.

\section{KEPUSTAKAAN}

\section{Buku-buku}

Andreas B. Subagyo, Sabda dalam Kata, Persiapannya. Bandung: Yayasan Kalam Hidup, 2000.

Basrowi \& Sukidin, Metode Penelitian Kualitatif. Surabaya: Insan Cendekia, 2002.

Darmaputra, Eka Menyembah dalam Roh dan Kebenaran. Jakarta: BPK Gunung Mulia. 2002.

Effendy, Onong Uchjana Ilmu Komunikasi - Teori dan Praktek. Bandung: Remaja Karya. 1986.

Subagyo, Andreas B. Pegantar Riset Kuantitatif dan Kualitatif. Bandung: Yayasan Kalam Hidup, 2004.

Sutanto, Hasan. Homiletik, Prinsip dan Metode Berkhotbah. Jakarta: BPK Gunung Mulia. 2004.

Tjandra. Lukas. Persiapan Khotbah Efekatif. Malang: Seminari Alkitab Asia Tenggara, 2002.

\section{Wawancara}

Amran, Wawancara dengan penulis, 03 Pebruari 2009.

TA (inisial) Wawancara dengan penulis, 21 Maret 2009. 